\title{
LEKSIKAL PENANDA UKURAN WAKTU BAHASA JAWA PADA MASYARAKAT DESA KLOPODUWUR, KECAMATAN BANJAREJO, KABUPATEN BLORA, JAWA TENGAH
}

\author{
JAVANESE LEXICAL MARKER OF TIME AMONG SOCIETY OF \\ KLOPODUWUR VILLAGE, BANJAREJO, BLORA, EAST JAVA
}

\author{
Siti Raudloh \\ Kantor Bahasa Provinsi NTB \\ Tanggal naskah masuk: 1 Mei 2012 \\ Tanggal revisi terakhir: 20 November 2012
}

\begin{abstract}
This study is aimed at describing the lexical marker of time, during day and night, in Klopoduwur village community. The data are collected through interview technique and then analyzed by using intralingual identity method. The result of analysis shows that Javanese has rich number of lexical markers of time which are not found in other languages. The word 'wayah' is only equaled to the words which mean 'circular or repetitive'. Alignment of words either in the form of free morpheme or polimorfemis on the formation of lexical marker of time measurement has a grammatical meaning 'time' and metaphorical meanings.
\end{abstract}

Keywords: lexical, word alignment, metaphorical meaning

\begin{abstract}
Abstrak
Penelitian ini bertujuan untuk mendeskripsikan leksikal penanda ukuran waktu dalam sehari semalam pada masyarakat Desa Klopoduwur. Metode pengumpulan data yang digunakan adalah metode cakap dan metode simak. Selanjutnya untuk menganalisis data menggunakan metode padan intraligual. Hasil analisis menunjukkan bahwa bahasa Jawa sangat kaya akan leksikal-leksikal penanda ukuran waktu yang tidak dimiliki oleh bahasa lain. Kata 'wayah' hanya bisa dijajarkan dengan kata yang mempunyai pesan makna 'melingkar atau berulang'. Penjajaran kata baik yang berupa morfem bebas maupun polimorfemis pada pembentukan leksikal penanda ukuran waktu mempunyai makna gramatikal 'waktu' dan makna metaforis.
\end{abstract}

Kata kunci: leksikal, penjajaran kata, makna metaforis

\section{Pendahuluan}

Bahasa pada dasarnya merupakan salah satu karakteristik murni hasil peradaban manusia dan merupakan metode non-instingtif untuk mengomunikasikan gagasan, perasaan, dan keinginan dengan bantuan simbol yang dihasilkan dengan sukarela.
Bahasa adalah representasi fonologis yang digunakan sebagai kebiasaan untuk menunjukkan makna dan kegiatan sosial, kebudayaan, fisik, fisiologi, mental, dan psikologis ${ }^{1}$. Bahasa yang kita kenal sekarang ini merupakan produk masyarakat masa lampau, dipelihara dan dikembangkan, 
serta diwariskan secara turun-temurun.

Bahasa tumbuh dan berkembang sejalan dengan masyarakat dan budaya penuturnya. Bahasa merupakan suatu yang tidak dapat dipisahkan dari kehidupan manusia karena dengan bahasa, manusia dapat mengungkapkan segala hal yang ada dalam pikiran dan perasaannya, yakni berkomunikasi ${ }^{2}$.

Dalam berkomunikasi, manusia memproduksi ujaran-ujaran yang berupa kalimat, frasa, klausa, kata atau leksikon. Leksikon dalam sebuah bahasa sengat banyak jumlahnya, misalnya leksikon kesusastraan, leksikon bidang pertanian, leksikon bidang kesehatan, leksikon penanda sifat, leksikon penanda waktu, dan lainlain.

Berbicara masalah leksikon penanda waktu, dalam konsep bahasa Indonesia ada waktu pagi, siang, sore, petang, malam, tengah malam, dan dini hari. Waktu-waktu tersebut tidak mempunyai batasan yang jelas, misalnya, ketika kita mengatakan "Selamat pagi, Pak", batasan pagi itu dari pukul berapa sampai dengan pukul berapa. Apakah orang juga akan menyapa "Selamat pagi, Pak" ketika situasi itu terjadi pada pukul 10.00. Lain halnya dalam bahasa Jawa kita mengenal penamaan waktu untuk pukul 10.00 yaitu "wayah wisan gawe", Pukul 17.30 yaitu Tibra layu (sandikolo). Kekayan leksikal bahasa Jawa tersebut menunjukkan keragaman budaya dalam kehidupan masyarakat Jawa.
Kajian ini memaparkan bentukbentuk leksikon penanda ukuran waktu bahasa Jawa pada masyarakat Desa Klopoduwur, khususnya leksikon penanda ukuran waktu dalam sehari semalam (24 jam). Menarik untuk diteliti karena secara historis Desa Klopoduwur merupakan pusat berkembangnya ajaran Samin Surosentiko yang memiliki latar belakang sejarah yang menarik perhatian para ahli. Menurut Nurudin ${ }^{3}$, masyarakat Samin terbentuk dari munculnya seorang tokoh bernama asli R. Kohar yang lahir di Desa Plosokediren, Randublatung, Blora pada tahun 1859, anak dari $\mathrm{R}$. Surowijoyo (atau Samin Sepuh). Agar lebih merakyat nama R. Kohar diganti menjadi Samin dan setelah menjadi guru kebatinan (dalam masyarakat Jawa pengaruh guru kebatinan atau paranormal amat kuat) nama itu dilengkapi dengan Surosentiko, sehingga menjadi Samin Surosentiko dan bergelar Panembahan Suryongalam. Oleh pengikut Saminisme sering disebut Ki (Kyai) Samin Surosentiko atau Ki (Kyai) Saminsurontiko. Sebagai guru kebatinan $\mathrm{Ki}$ Samin menciptakan istilah-istilah khusus yang dapat memperkaya variasi bahasa Jawa di Blora dan menyebar yang dibawa oleh para pengikutnya. 


\subsection{Landasan Teori}

\subsubsection{Leksikon dan Kosakata}

Secara etimologi leksikal adalah bentuk adjektiva dari kata leksikon yang terlebih dahulu menurunkan kata leksem.

Dalam kajian linguistik istilah leksem digunakan dalam dua bidang subkajian, yaitu kajian morfologi dan kajian semantik. Dalam kajian morfologi, leksem diartikan sebagai 'bentuk' yang akan menurunkan sebuah atau sejumlah $\mathrm{kata}^{4}$. Sebagai sebuah bentuk, leksem belum digunakan dalam satu ujaran; yang digunakan dalam ujaran yang nyata adalah kata. Misalnya bentuk PUKUL (dalam konvensi 'morfologi' leksem ditulis dengan huruf kapital semua) adalah sebuah leksem yang dapat menurunkan kata-kata memukul, dipukul, terpukul, pukul, pukulan, pemukul, pemukulan, dan sebagainya, sedangkan dalam kajian semantik istilah leksem digunakan untuk mewadahi konsep satuan bahasa yang memiliki satu satuan makna. Oleh karena prinsipnya adalah satuan makna, maka bentuk-bentuk seperti meja, kucing, keras kepala, menamakan, dan menganaktirikan adalah termasuk dalam konsep leksem. Jadi, secara semantik yang disebut leksem bisa berupa kata dasar, kata gabung, kata berimbuhan, maupun bentuk-bentuk yang disebut ungkapan atau idiom.

Leksikon berasal dari kata Yunani kuno lexicon yang berarti 'kata', 'ucapan', atau 'cara berbicara'5. Dalam linguistik aliran Britania digunakan istilah leksis $^{6}$. Kridalaksana ${ }^{7}$ mendefinisikan leksikon adalah komponen bahasa yang memuat semua informasi tentang makna dan pemakaian kata dalam bahasa, atau kekayaan kata yang dimiliki seorang pembicara, penulis, atau suatu bahasa; kosakata atau perbendaharaan kata.

Selanjutnya, $\mathrm{Chaer}^{8}$ menjelaskan, istilah leksikon lazim digunakan untuk mewadahi konsep "kumpulan leksem" dari satu bahasa, baik kumpulan sacara keseluruhan maupun secara sebagian. Dalam kepustakaan Indonesia kita mempunyai leksikon Malaysia ${ }^{9}$ yang berisi sejumlah kata bahasa Malaysia yang secara semantik dan gramatika berbeda-beda dengan kata-kata dalam bahasa Indonesia.

Dari uraian di atas, dapat disimpulkan bahwa dalam peristilahan sekarang barangkali istilah leksikon ini bisa disepadankan dengan istilah kosakata yang sudah lazim digunakan dalam pemelajaran bahasa. Kata leksikon yang berstatus nomina memiliki bentuk adjektivanya yang juga sudah lazim digunakan yaitu leksikal, dalam arti bersifat leksikon, seperti terdapat pada frase makna leksikal, kajian leksikal, dan semantik leksikal.

Istilah kosakata muncul ketika para linguis Indonesia sedang giatgiatnya mencari kata atau istilah yang tidak berbau barat. Asal-usul kata ini menurut Notosudirjo ${ }^{10}$ berasal dari 
bahasa Sansekerta koca yang berarti 'perbendaharaan', 'kekayaan', 'khazanah', dimajemukkan dengan kata khata yang berarti 'kata'. Dalam Kamus Besar Bahasa Indonesia kata 'kosakata' didaftarkan sebagai sebuah entri yang ditulis serangkai dan diberi makna 'perbendaharaan kata'.

Berdasarkan penjelasan di atas, dalam kajian ini yang dimaksudkan ke dalam satuan kosakata hanyalah buturbutir leksikal (lexical items) penanda ukuran waktu bahasa Jawa baik yang berupa morfem dasar (bebas dan terikat) maupun yang berupa gabungan morfem dalam bentuk kata berimbuhan, berulang, maupun bentuk majemuk .

\subsubsection{Konsep Kala dan Keterangan Waktu}

Kala atau tenses adalah informasi dalam kalimat yang menyatakan waktu terjadinya perbuatan, kejadian, tindakan, atau pengalaman yang disebutkan di dalam predikat Chaer ${ }^{11}$, Kala ini lazimnya menyatakan waktu sekarang, sudah lampau, dan akan datang. Beberapa bahasa menandai kala itu secara morfemis; artinya, pertanyaan kala itu ditandai dengan bentuk kata tertentu pada verbanya. Bahasa Indonesia tidak menandai kala secara morfemis, melainkan secara leksikal. Dalam bahasa Indonesia banyak orang yang mengelirukan konsep kala dengan konsep keterangan waktu sebagai fungsi sintaksis; sehingga mereka mengatakan kala sudah, sedang, dan akan adalah keterangan waktu. Padahal keterangan waktu, dan keterangan lainnya, sebagai fungsi sintaksis memberi keterangan terhadap keseluruhan kalimat. Posisinya pun dapat dipindahkan ke awal kalimat atau ke tempat lain; sedangkan kala terikat pada verbanya atau predikatnya. Penyebab kekeliruan itu barangkali karena kata-kata seperti sudah, sedang, dan akan itu "sejenis" dengan kata-kata kemarin, tadi, dan besok yang menyatakan waktu; dan kata yang terakhir ini memang dapat mengisi fungsi keterangan. Mungkin juga karena dalam tata bahasa tradisional, istilah keterangan digunakan untuk dua macam konsep, yaitu konsep fungsi sintaksis, dan konsep kategori sintaksis.

Dalam membicarakan waktu, Benveniste $^{12}$ dalam membedakan tiga pengertian, yaitu: (1) Waktu fisis (temps physique), yakni waktu yang secara alamiah kita alami, yang sifatnya sinambung, Iinear, dan tak terhingga. Waktu fisis berjalan terus tanpa dapat kita alami lagi. (2) Waktu kronis (temps chronique), yakni waktu yang dipikirkan kembali atau dikonseptualisasikan oleh manusia berdasarkan suatu atau sejumlah peristiwa yang ditetapkan secara konvensional oleh suatu masyarakat sebagai titik acuan dalam waktu fisis. (3) Waktu kebahasaan (temps hnguistigice), yakni waktu yang dilibatkan dalam tuturan kita dan dalam sistem bahasa yang kita pakai. Ketiga 
pengertian mengenai waktu yang dikemukakan Benveniste itu sangat penting untuk memahami konsep manusia tentang waktu. Bagi manusia, waktu yang sebenarnya dirasakan ialah waktu fisis. Manusia hidup di dalam waktu yang terus berjalan tanpa dapat kembali lagi ke waktu lampau. Akan tetapi, dengan mengkonseptualisasi waktu manusia dapat menjelajahinya, sehingga, ia dapat mengarungi sejarah, masa kini, dan hari depannya. Bahkan manusia dapat membayangkan waktu dalam sesuatu pembagian yang beraturan. Untuk menetapkan pembagian yang beraturan itu, biasanya manusia menentukan secara konvensional suatu peristiwa sebagai titik acuan dalam waktu fisis dan kemudian menetapkan pula pembagiannya dalam sejumlah penggalan. Misalnya tahun 1 Saka konon dihubungkan saat mendaratnya Ajisaka di Pulau Jawa. Ada pula yang mengabarkan, bahwa permulaannya adalah saat Raja Sariwahana Ajisaka naik tahta di India ${ }^{13}$. Selanjutnya tahun dibagi atas bulan (12 bulan), bulan (30 hari), minggu (7 hari), dan hari (24 jam, atau satu putaran bumi, atau jarak waktu antara matahari terbit dan matahari terbit, atau antara matahari terbenam dan matahari terbenam).

\subsubsection{Penjajaran Kata dalam Frase}

Dalam sebuah kalimat ada fungsi-fungsi sintaksis tertentu yang disebut subjek, predikat, objek, dan keterangan. Fungsi-fungsi sintaksis itu diisi atau diduduki oleh kategorikategori tertentu. Fungsi itu mungkin diisi satu kata atau lebih. Dua kata atau lebih yang mengisi fungsi sintaksis tertentu di sebut frasa ${ }^{14}$.

Dilihat dari persamaan dan perbedaan distribusi frasa dengan unsur-unsurnya, frasa dibedakan atas frasa endosentris dan frasa eksosentris. Disebut frasa endosentris bila distribusi frasa secara keseluruhan sama dengan semua atau salah satu unsurnya, sedangkan kalau tidak ada satu pun dari unsur frasa itu yang mempunyai distribusi yang sama dengan frasa itu sendiri, disebut frasa eksosentrik ${ }^{15}$.

Selanjutnya, $\quad$ Soedjarwo $^{16}$ menyebutkan, frasa endosentris yang memiliki satu unsur yang sama dengan keseluruhan frasa itu disebut frasa endosentris atributif, sedangkan frasa endosentris yang semua unsurnya mempunyai distribusi yang sama dengan frasa itu sendiri, disebut frasa endosentris yang koordinatif.

Dalam bahasa Indonesia, ada tiga macam sarana untuk membangun hubungan struktural pada tataran frasa. Ketiga sarana itu ialah penjajaran, perangkaian, dan persendian. Penjajaran artinya penyebutan atau peletakan kata-kata dalam urutan langsung. Dengan penjajaran itu dapat dinyatakan bermacam-macam hubungan makna ${ }^{17}$. Perangkaian ialah penggunaan kata perangkai, atau oleh Sudaryanto18, disebut peligaturan. Kata perangkai digunakan apabila hubungan makna antara unsur-unsur 
dalam frasa itu tidak cukup jelas dinyatakan dengan penjajaran. Sedangkan persendian merupakan bagian dari intonasi.

\subsubsection{Teori Semantik}

Untuk menggali makna leksikal penanda ukuran waktu, digunakan pendekatan semantik, khususnya tentang makna. Djajasudarma ${ }^{19}$ menyebutkan pada dasarnya kata itu memiliki makna kognitif (denotatif, deskriptif), makna konotatif, dan makna emotif. Kata dengan makna kognitif digunakan pada kehidupan sehari-hari dan bidang teknik. Kata konotatif di dalam bahasa Indonesia cenderung negatif, sedangkan kata emotif memiliki makna positif.

Selain jenis makna yang telah disebutkan di atas, masih banyak jenisjenis makna berdasarkan berbagai sumber yang dikemukakan oleh para ahli bahasa, yaitu: makna sempit, luas, leksikal, gramatikal, referensial, kontruksi, idesional, proposisi, pusat, piktorial, idiomatik, dan metaforis.

\section{Hasil dan Pembahasan}

Berdasarkan data yang diperoleh, ditemukan 24 leksikal penanda ukuran waktu dalam satu hari (24 jam) pada masyarakat Desa Klopoduwur. Berikut ini akan dipaparkan masing-masing leksikon penanda ukuran waktu tersebut secara berturut-turut.

\subsection{Leksikal Penanda Ukuran Waktu dalam Sehari Semalam \\ Leksikon penanda ukuran waktu} dalam sehari semalam (24) jam bahasa Jawa masyarakat Desa Klopoduwur adalah sebagai berikut:

(1) Wayah Byar [wayah byar]. Leksikal penanda ukuran waktu ini terdiri atas dua leksikon, yaitu wayah yang berarti 'waktu; wanci; masa' dan byar yang berarti 'terbuka; menjadi terang'. Jadi wayah byar bisa diartikan waktu ketika matahari terbuka atau terbit, menurut ukuran waktu jam nasional kira-kira pukul 06.00. Semula bumi diselimuti oleh kegelapan malam kemudian matahari terbit dan seketika itu menjadi terang. Dalam kamus bahasa Jawa ditemukan kata ambyar yang berarti 'bertebaran', dengan demikian kata byar merupakan bentuk dasar yang menunjukkan makna emotif, bahwa waktu itu benar-benar matahari terbit, sehingga wayah byar ini memiliki makna simbolis tentang awal mula orang beraktifitas.

Wayah byar merupakan jenis frasa endosentris atributif yang berstruktur Adv + A. Hubungan makna yang timbul dari disejajarkannya kata wayah dan byar adalah makna idiomatis, yaitu menunjukkan waktu tertentu ketika matahari sudah terbit.

Contoh: Mbah Lasio mele'an sampek wayah byar

'Mbah Lasio begadang sampai pukul 06.00.

(2) Wayah Gumatel [wayah gumat2l]. Leksikal penanda ukuran 
waktu ini terdiri atas dua leksikon, yaitu wayah dan gumatel. Wayah barati 'waktu; wanci', sedangkan gumatel secara khusus tidak di temukan dalam kamus bahasa Jawa, kecuali kata dasar gatel 'gatal' yang mendapat sisipan (infiks) um menjadi gumatel. Kata gumatel mengandung makna emotif, yaitu makna yang timbul akibat adanya reaksi pembicara atau sikap pembicara terhadap sesuatu yang dipikirkan atau dirasakan, Sipley ${ }^{20}$. Saat mendengar kata wayah gumatel seseorang akan berfikir bagaimana polah tingkah orang yang badannya merasa gatal. Dengan demikian wayah gumatel memiliki makna simbolis tentang waktu ketika orang sedang sibuk-sibuknya bekerja, yaitu kira-kira pukul 09.00. Selain wayah gumatel penanda waktu ini juga disebut wayah lingsir wetan [wayah linsIr wetan] yang berarti waktu ketika matahari condong ke arah timur.

Penjajaran morfem bebas wayah dengan morfem polimofemis gumatel pada frasa endosentris atributif wayah gumatel mempunyai makna metaforis, yaitu mengibaratkan waktu ketika orang sibuk bekerja dengan orang yang sibuk menggaruk badannya karena merasa gatal.

(3) Wayah Pecat sawed [wayah

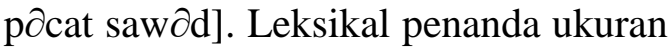
waktu ini terdiri atas tiga leksikon, yaitu wayah sebagaimana yang telah dijelaskan di atas, pecat berarti 'lepas; bebas; dikeluarkan; terpisah' dan sawed berarti 'kayu penggandeng sapi atau kerbau waktu membajak sawah'.
Jadi wayah pecat sawet berarti waktu ketika para petani melepaskan kayu penggandeng sapi waktu membajak sawah untuk beristirahat sejenak. Biasanya waktu ini dipergunakan oleh petani untuk mindho (sarapan kedua) dan memberi makanan binatang ternaknya sebelum melanjutkan pekerjaannya. Menurut perkiraan waktu nasional wayah pecat sawed kira-kira pukul 10.00. Selain wayah pecat sawed masyarakat Desa Klopoduwur menyebut waktu ini dengan wayah wisan gawe [wayah wisan gawe] yang artinya tidah jauh berbeda dengan wayah pecat sawed. Wisan berarti 'sudah; selesai' dan gawe berarti 'pekerjaan; membajak'.

Wayah Pecat sawed termasuk jenis frasa endosentris atributif dengan susunan berlapis-lapis. Lapisan-lapisan itu berupa rangkaian unsur pusat dan unsur tambahan. Unsur pusat pecat dan unsur tambahan sawed pada pecad sawed menjadi unsur pusat pada wayah pecad sawed. Hubungan makna yang timbul dari disejajarkannya kata wayah, pecat dan sawed adalah makna metaforis, yaitu menunjukkan waktu tertentu.

(4) Wayah Tengange [wayah tônaךe]. Leksikal penanda ukuran waktu ini terdiri atas dua leksikon, yaitu wayah sebagaimana yang telah dijelaskan di atas, dan tengange. Dalam kamus bahasa Kawi-Jawa tengange berarti 'srengenge sederengipun lingsir wetan'. Jadi wayah tengange berarti waktu ketika matahari condong ke 
timur dari titik tertinggi. Menurut perkiraan waktu nasional wayah tengange kira-kira pukul 11.30.

Wayah Tengange termasuk jenis frasa endosentris atributif yang berstruktur Adv + A. Hubungan makna yang timbul dari disejajarkannya kata wayah dan tengange adalah makna metaforis, yaitu menunjukkan waktu tertentu.

(5) Wayah bedhuk [wayah bədUk]. Leksikal penanda waktu ini terdiri atas dua leksikon, yaitu wayah dan bedhuk. Wayah berarti 'waktu; wanci' dan bedhuk berarti 'bedhuk'. Wayah bedhuk berarti waktu ketika saat shalat dzuhur tiba yang biasanya ditandai dengan dipukulnya beduk di masjid-masjid sebagai media panggilan untuk melaksanakan ibadah sholat, atau menurut perkiraan waktu nasional kirakira pukul 12.00. Meskipun masyarakat Desa Klopoduwur mengenal waktu beduk, namun masjid yang berada di Desa Klopoduwur tidak ditemukan lagi beduk. Mereka tidak lagi memakai beduk dan menggantikannya dengan mikrofon.

Wayah bedhuk termasuk jenis frasa endosentris atributif yang berstruktur Adv $+\mathrm{N}$. Hubungan makna yang timbul dari disejajarkannya kata wayah dan beduk adalah makna metaforis, yaitu menunjukkan waktu tertentu.

(6) Wayah bar bedug [wayah bar bədUk]. Sebagaimana telah dijelaskan di atas wayah bedhuk berarti waktu ketika ditabuhnya beduk sebagai penanda datangnya waktu shalat dzuhur. Selanjutnya leksikon bar sebagai unsur tambahan pada frasa endosentris atributif wayah bar bedhuk mempunyai arti 'bubar; setelah; usai'. Jadi wayah bar bedhuk berarti waktu setelah shalat dzuhur, atau menurut perkiraan waktu nasional kira-kira pukul 13.00. Hubungan makna yang timbul dari disejajarkannya kata wayah, bar dan behuk adalah makna gramatikal 'waktu'.

\section{(7) Wayah Lingsir Kulon}

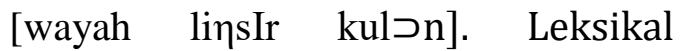
penanda ukuran waktu ini terdiri atas tiga leksikon, yaitu wayah, lingsir, dan kulon. Lingsir berarti 'bergerak dari tempatnya; bergerak ke samping; bergerak ke bawah (dari titik tinggi); sudah miring; sudah condong'. Kulon berarti 'barat'. Jadi lingsir kulon berarti waktu ketika matahari mulai bergerak condong ke arah barat, menurut perkiraan waktu nasional kira-kira pukul 14.00.

Wayah lingsir kulon termasuk jenis frasa endosentris atributif dengan susunan berlapis-lapis. Lapisan-lapisan itu berupa rangkaian unsur pusat dan unsur tambahan. Unsur pusat lingsir dan unsur tambahan kulon pada lingsir kulon menjadi unsur pusat pada wayah lingsir kulon. Hubungan makna yang timbul dari disejajarkannya kata wayah, lingsir, dan kulon adalah makna metaforis, yaitu menunjukkan waktu tertentu.

(8) Wayah Ngasar [wayah

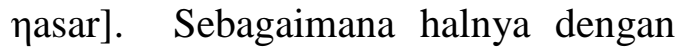


wayah bedhuk, wayah ngasar menunjukkan masuknya waktu salat asar. Meskipun biasanya panggilan untuk ibadah salat asar ini juga menggunakan beduk, tapi masyarakat Desa Klopoduwur tidak menyebutnya dengan wayah bedhuk asar tapi hanya menyebut wayah ngasar. Menurut perkiraan waktu nasional wayah ngasar ini kira-kira pukul 15.00.

Penjajaran dua morfem bebas wayah dan ngasar dalam frasa ini mengandung makna gramatikal 'waktu'.

(9) Wayah bar ngasar [wayah bar nasar] Sebagaimana telah dijelaskan di atas wayah ngasar menunjukkan masuknya waktu salat asar. Selanjutnya leksikon bar sebagai unsur tambahan pada frasa endosentris atributif wayah bar ngasar mempunyai arti 'bubar; setelah; usai'. Jadi wayah bar ngasar berarti waktu setelah salat asar, atau menurut perkiraan waktu nasional kira-kira pukul 15.30. Hubungan makna yang timbul dari disejajarkannya kata wayah, bar, dan ngasar adalah makna gramatikal ‘ waktu'.

(10) Wayah Tunggang gunung

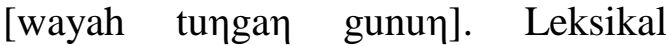
penanda waktu ini terdiri atas tiga leksikon, yaitu wayah, tunggang, dan gunung. Tunggang berarti 'tumpak' gunung 'gunung'. Tunggang gunung berarti waktu menjelang sore hari ketika matahari di atas punggung gunung sebelah barat. Menurut perkiraan waktu nasional wayah tengange kira-kira pukul 17.00

Wayah tunggang gunung termasuk jenis frasa endosentris atributif dengan susunan berlapislapis. Sebagaimana yang telah dijelaskan di atas. Frasa ini berstruktur $\mathrm{Adv}+\mathrm{V}+\mathrm{N}$. Hubungan makna yang timbul dari disejajarkannya kata wayah, tunggang dan gunung adalah makna metaforis, yaitu mengibaratkan waktu ketika matahari berada di punggung gunung dengan waktu tertentu.

(11) Wayah tibra layu [wayah tibrつ layu]. Leksikal penanda waktu ini terdiri atas tiga leksikon, wayah, tibra, dan layu. Tibra dalam kamus bahasa Jawa berarti 'kuat; keras' dan layu berarti 'menghilang', selain wayah tibra layu waktu ini juga disebut dengan wayah sandekolo [wayah sandek داد], yang berarti 'gurat merah di langit senja; senjakala; petang hari'. Jadi wayah Tibra layu atau wayah sandekolo berarti waktu ketika matahari terbenam dan tampak guratan merah di langit atau menurut perkiraan waktu nasional kira-kira pukul 17.30.

Wayah tibra layu termasuk jenis frasa endosentris atributif dengan susunan berlapis-lapis. Lapisan-lapisan itu berupa rangkaian unsur pusat dan unsur tambahan. Unsur pusat tibra dan unsur tambahan layu pada tibra layu menjadi unsur pusat pada wayah tibra layu. Hubungan makna yang timbul dari disejajarkannya kata wayah, tibra 
dan layu adalah makna metaforis, yaitu menunjukkan waktu tertentu.

(12) Wayah

Maghrib, [wayah magrIb], sama halnya dengan yang telah dijelaskan di atas wayah maghrib menunjukkan masuknya waktu salat maghrib. Selain wayah maghrib waktu ini juga desebut dengan wayah surup [wayah surUp]. Surup berarti 'turun; terbenamnya (matahari, bulan, bintang); petang hari' jadi wayah surup berarti waktu ketika matahari benar-benar terbenam, atau menurut perkiraan waktu nasional kirakira pukul 18.00.

Penjajaran dua morfem bebas wayah dan maghrib atau surup pada frasa endosentris atributif memiliki makna gramtikal 'waktu'.

(13) Wayah bar maghrib [wayah bar magrIb], sama halnya dengan wayah bar dzuhur dan wayah bar asar yang telah dijelaskan diatas. Wayah bar maghrib menunjukkan waktu setelah salat maghrib, kira-kira pukul 18.30.

(14) Wayah Ngisak [wayah ๆisa?], sama dengan wayah maghrib, wayah ngisak menunjukkan masuknya waktu salat isya, kira-kira pukul 19.00.

(15) Wayah bar ngisak [wayah bar pisa?], yaitu waktu setelah salat isya, kira-kira pukul 20.00.

(16) Wayah Sirep bocah [wayah sirop bocah]. Leksikal penanda ukuran waktu ini terdiri atas tiga leksikon, yaitu wayah sebagaimana dijelaskan di atas, sedangkan sirep berarti 'sunyi; tanpa suara; tidur; diam', dan bocah berarti 'anak kecil'. Dengan demikian, wayah sirep bocah bisa diartikan waktu ketika anak-anak kecil sudah tidur, atau kira-kira pukul 20.00.

Wayah sirep bocah termasuk jenis frasa endosentris atributif dengan susunan berlapis-lapis. Lapisan-lapisan itu berupa rangkaian unsur pusat dan unsur tambahan. Unsur pusat sirep dan unsur tambahan bocah pada sirep bocah menjadi unsur pusat pada wayah sirep bocah. Penjajaran tiga morfem bebas wayah, sirep, dan bocah pada frasa ini mempunyai makna metaforis, yaitu menunjukkan waktu tertentu ketika anak-anak sudah tidur.

(17) Wayah Sirep wong [wayah sir $\partial \mathrm{p} w \supset \eta]$, sebagaimana telah dijelaskan pada wayah sirep bocah di atas, wayah sirep wong berarti waktu ketika orang-orang dewasa tidur, kirakira pukul 23.00.

(18) Wayah bedhuk bengi

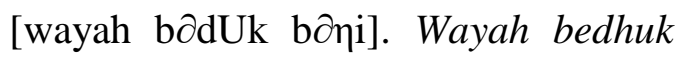
bengi ini kebalikan dari wayah bedhuk pada siang hari yang menunjukkan waktu masuknya salat dzuhur. Yang membedakannya adalah wayah bedhuk bengi tidak ditandai dengan dipukulnya beduk di masjid, tetapi ditandai dengan dipukulnya kentongan para penduduk desa yang sedang ronda malam, kirakira pukul 24.00. Pada umumnya orang Jawa menyebut waktu ini dengan wayah tengah wengi.

(19) Wayah Lingsir wengi

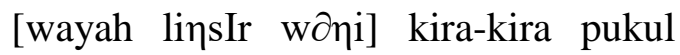
01.00. Kata lingsir yang dijajarkan dengan kata wengi berbeda dengan 
kata lingsir yang dijajarkan dengan kata wetan dan kulon. Makna lingsir yang dijajarkan dengan kata wetan dan kulon ada kaitannya dengan matahari yang bergerak kesamping dari titik tertinggi, sedangkan kata lingsir yang dijajarkan dengan kata wengi mempunyai arti 'mundur; berkurang; susut'. Jadi lingsir wengi bisa diartikan waktu ketika malam mulai berkurang atau susut.

Contoh: Malinge kira-kira mlebu omah kuwi wayah lingsir wengi pas sing duwe omah turu pules.

'Pencuri masuk rumah itu pukul 01.00 ketika penghuninya tidur lelap'.

(20) Wayah Titiyoni [wayah titiyつni]. Leksikal penanda waktu ini terdiri atas dua leksikon, yaitu wayah artinya sudah dijelaskan di atas dan titiyoni. Dalam kamus bahasa Jawa tidak ditemakan kata ini, kecuali kata titi dan yoni. titi artinya 'hari menurut peredaran bulan' dan yoni artinya 'sempurna; kekuatan gaib; sakti', sedangkan dalam kamus bahasa KawiJawa ditemukan kata titisoni yang artinya 'sirep; tidur'. Menurut penulis makna wayah titiyoni adalah sama dengan titisoni, yaitu waktu ketika orang-orang sedang nyenyak tidur atau sirep, menurut ukuran waktu nasional kira-kira pukul 02.00 .

(21) Wayah Jago kluruk sepisan [wayah jago klurU? sopisan]. Zaman dulu masyarakat Jawa belum mengenal jam, maka untuk menandai waktu, mereka menggunakan tandatanda alam yang ada di sekitarnya, terutama bagi mereka yang tinggal di pedesaan. Misalnya ketika ayam jantan berkokok yang pertama kali, masyarakat Desa Klopoduwur menyebutnya dengan Wayah Jago kluruk sepisan kira-kira pukul 03.00.

Wayah jago kluruk sepian termasuk jenis frasa endosentris atributif dengan susunan berlapislapis. Lapisan-lapisan itu berupa rangkaian unsur pusat dan unsur tambahan. Unsur pusat jago dan unsur tambahan kluruk pada jago kluruk menjadi unsur pusat pada wayah jago kluruk; wayah jago kluruk pada gilirannya menjadi unsur pusat pula setelah mendapat unsur tambahan sepisan menjadi wayah jago kluruk sepisan. Hubungan makna yang timbul dari disejajarkannya kata wayah, jago, kluruk dan sepisan adalah makna metaforis, yang menunjukkan waktu tertentu.

(22) Wayah subuh [wayah subUh], sama dengan wayah ngasar, maghrib, dan ngisak. Wayah subuh menunjukkan masuknya waktu salat subuh. Masyarakat Desa Klopoduwur juga menyebut waktu ini dengan wayah jago kluruk ping pidho [wayah jago klurU? pi pindho] kira-kira pukul 04.00 .

(23) Wayah Jago kluruk ping telu [wayah jago klurU? pi tolu]. Sebagaimana dijelaskan di atas, leksikal penanda ukuran waktu ini mempunyai arti ketika ayam jantan berkokok untuk yang ketiga kalinya, 
atau menurut perkiraan waktu nasional kira-kira pukul 05.00.

Wayah jago kluruk ping telu termasuk jenis frasa endosentris atributif dengan susunan berlapislapis. Lapisan-lapisan itu berupa rangkaian unsur pusat dan unsur tambahan. Unsur pusat jago dan unsur tambahan kluruk pada jago kluruk menjadi unsur pusat pada wayah jago kluruk; wayah jago kluruk pada gilirannya menjadi unsur pusat pula setelah mendapat unsur tambahan ping telu menjadi wayah jago kluruk ping telu. Hubungan makna yang timbul dari disejajarkannya kata wayah, jago, kluruk, dan ping telu adalah makna metaforis, yang menunjukkan waktu tertentu.

(24) Wayah saput lemah [wayah sapUt 12mah], leksikal penanda ukuran waktu ini terdiri atas tiga leksikon, yaitu wayah sebagaimana yang dijelaskan di atas, saput berarti 'tutup; penutup' dan lemah berarti 'tanah; bumi'. Jadi wayah saput lemah berarti waktu ketika tanah mulai remang-remang di pagi hari, yaitu ketika bumi yang tertutup kegelapan malam mulai tersingkap oleh fajar timur. Menurut perkiraan waktu nasional kira-kira pukul 05.30.

Wayah saput lemah termasuk jenis frasa endosentris atributif dengan susunan berlapis-lapis. Lapisan-lapisan itu berupa rangkaian unsur pusat dan unsur tambahan. Unsur pusat saput dan unsur tambahan lemah pada saput lemah menjadi unsur pusat pada wayah saput lemah. Hubungan makna yang timbul dari disejajarkannya kata wayah, saput dan lemah adalah makna metaforis, yaitu menunjukkan waktu tertentu.

\section{Simpulan dan Saran \\ 3.1 Simpulan}

Berdasarkan pembahasan di atas, beberapa hal yang menarik dapat disimpulkan bahwa bahasa Jawa sangat kaya akan leksikal-leksikal penanda ukuran waktu yang tidak dimiliki oleh bahasa lain di dunia. Dalam sehari semalam masyarakat Jawa Desa Klopoduwur mengenal 24 leksikal penanda ukuran waktu. Leksikalleksikal tersebut selalu diawali dengan kata wayah (waktu, masa). Kata wayah hanya bisa dijajarkan dengan kata yang mempunyai arti hierarki tak bercabang yang berbentuk spiral (helical), yaitu hierarki yang mempunyai cabang atau pesan melingkar dan berulang, misalnya periode waktu dalam sehari semalam (wayah byar, wayah pecat sawed, wayah linsir wengi, dll.), dan musim (wayah rendeng, wayah ketigo, wayah laboh, dll.).

Penjajaran kata baik yang berupa morfem bebas maupun polimorfemis pada pembentukan leksikal penanda ukuran waktu yang berbentuk frasa endosentris atributif mempunyai makna gramatikal 'waktu' dan makna metaforis.

Atribut atau unsur tambahan frasa endosentris atributif pada leksikal penanda ukuran waktu, dapat 
mendahului atau mengikuti unsur pusat. Dengan kata lain unsur tambahan itu dapat terletak di kanan atau di kiri unsur pusat, atau susunannya ada yang MD ada pula yang DM. hal ini terjadi karena frasa endosentris atributif mempunyai susunan yang berlapis-lapis, misalnya wayah jago kluruk ping telu, wayah lingsir kulon, dan lain-lain.

\subsection{Saran}

Penggalian makna penanda ukuran waktu pada penelitian ini masih sangat dangkal, kiranya penelitian selanjutnya bisa menggali maknamakna yang terkandung dalam leksikal penanda ukuran waktu tidak terbatas pada waktu dalam sehari semalam, tetapi juga waktu dalam satu minggu, pasaran, bulan, tahun, windu, wuku, dan musim.

\section{DAFTAR PUSTAKA}

${ }^{1}$ Ma'mur, Ilzamudin. 2006. Pijar-pijar Pemikiran Bahasa dan Budaya. Jakarta: CV. Diadit Media.

${ }^{2}$ Djojosuroto, Kinayati. 2007. Filsafat Bahasa. Yogyakarta: Pustaka Book Publisher.

${ }^{3}$ Nurudin. 2003. Agama Tradisional Potret Kearifan Masyarakat Samin dan Tengger. Yogyakarta: LKiS.

${ }^{4}$ Chaer, Abdul. 2008. Morfologi Bahasa Indonesia (Pendekatan Proses). Jakarta: PT Rineka Cipta.

${ }^{5}$ Chaer, Abdul. 2007. Leksikologi dan Leksikografi Indonesia. Jakarta: PT Rineka Cipta.

${ }^{6}$ Kushartanti. 2005. Pesona Bahasa: Langkah Awal Memahami Linguistik. Jakarta: Gramedia Pustaka Utama.

${ }^{7}$ Kridalaksana, Harimurti. 2008. Kamus Linguistik. Jakarta: PT. Gramedia Pustaka Utama.

${ }^{8}$ Chaer, Abdul. 2007. Leksikologi dan Leksikografi Indonesia. Jakarta: PT Rineka Cipta.

${ }^{9}$ Kridalaksana, Harimurti. 1974. Leksikon Malaysia. Jakarta: Lembaga Riset Kebudayaan Nasional.

${ }^{10}$ Notosudirjo, Suwandi. 1979. Pengetahuan Bahasa Indonesia: Etimologi. Jakarta : PT. Mutia

${ }^{11}$ Chaer, Abdul. 2009. Sintaksis Bahasa Indonesia (Pendekatan Proses). Jakarta: PT Rineka Cipta. 
${ }^{12}$ Benveniste,1974. http://www.lontar.ui.ac.id// http://www.lontar.ui.ac.id// diunduh tanggal 16 Juni 2012.

${ }^{13}$ Purwadi. 2006. Petungan Jawa Menentukan Hari Baik dalam Kalender Jawa. Yogyakarta: Pinus Book Publisher.

${ }^{14}$ Verhar, J.W.M. 2008. Azas-Azas Linguistik Umum. Cetakan Ketiga. Yogyakarta: Gadjah Mada University Press.

${ }^{15}$ Soedjarwo. 1989. Penjajaran Kata dalam Frasa. Pidato Pengukuhan Guru Besar dalam Ilmu Bahasa Indonesia. Semarang: Fakultas Sastra Universitas Diponegoro.

${ }^{16}$ Soedjarwo. 1989. Penjajaran Kata dalam Frasa. Pidato Pengukuhan Guru Besar dalam Ilmu Bahasa Indonesia. Semarang: Fakultas Sastra Universitas Diponegoro.

${ }^{17}$ Soedjarwo. 1989. Penjajaran Kata dalam Frasa. Pidato Pengukuhan Guru Besar dalam Ilmu Bahasa Indonesia. Semarang: Fakultas Sastra Universitas Diponegoro.

${ }^{18}$ Soedjarwo. 1989. Penjajaran Kata dalam Frasa. Pidato Pengukuhan Guru Besar dalam Ilmu Bahasa Indonesia. Semarang: Fakultas Sastra Universitas Diponegoro.

${ }^{19}$ Djajasudarma, T. Fatimah. 1999. Semantik 2: Pemahaman Ilmu Makna. Bandung: Refika Aditama.

${ }^{20}$ Mansoer, Pateda. 2001. Semantik Leksikal. Jakarta: Rineka Cipta. 